\title{
Acrocomia aculeata fruits from three regions in Costa Rica: an assessment of biometric parameters, oil content and oil fatty acid composition to evaluate industrial potential
}

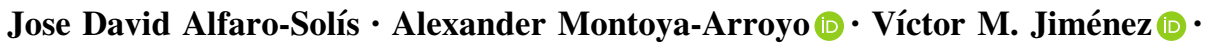 \\ Elizabeth Arnáez-Serrano (D) Jason Pérez (D) - Walter Vetter (i) \\ Jan Frank (i) - Iris Lewandowski (i)
}

Received: 27 January 2020/ Accepted: 11 June 2020/Published online: 23 June 2020

(C) The Author(s) 2020

\begin{abstract}
Due to increased global demand for vegetable oils, diversification of the supply chain with sustainable sources is necessary. Acrocomia aculeata has recently gained attention as a multi-purpose, sustainable crop for oil production. However, the information necessary for effective selection of promising varieties for agricultural production is lacking. The aim of this study was to assess variability in fruit morphology and oil composition of individual Acrocomia aculeata plants growing wild in different
\end{abstract}

Jose David Alfaro-Solís and Alexander Montoya-Arroyo have contributed equally to the development of the manuscript.

J. D. Alfaro-Solís · E. Arnáez-Serrano · J. Pérez

School of Biology, Instituto Tecnológico de Costa Rica,

Cartago, Costa Rica

e-mail: davidalfa00@gmail.com

E. Arnáez-Serrano

e-mail: earnaez@itcr.ac.cr

J. Pérez

e-mail: jasperez@itcr.ac.cr

\section{A. Montoya-Arroyo · J. Frank}

Institute of Nutritional Sciences, Department of Food

Biofunctionality (140b), University of Hohenheim,

70599 Stuttgart, Germany

e-mail: alexander.montoya-arroyo@uni-hohenheim.de

J. Frank

e-mail: jan.frank@uni-hohenheim.de climatic regions of Costa Rica. Fruits at the same ripening stage were collected at three locations, and biometric features, oil content, fatty acid composition of oils from kernels and pulp, as well as fiber composition of husks were determined. Biometric parameters showed high variability among the regions assessed. Moreover, oil content and relative proportions of unsaturated fatty acids were higher at the most tropical location, whereas lauric acid content was lowest under these conditions, indicating a potential environmental effect on oil composition. Pulp oil content correlated positively with annual precipitation and relative humidity, but no clear relation to

V. M. Jiménez

CIGRAS/IIA, Universidad de Costa Rica,

San Pedro 2060, Costa Rica

e-mail: victor.jimenez@ucr.ac.cr

V. M. Jiménez · J. Frank

University of Hohenheim, Food Security Center (791),

70599 Stuttgart, Germany

\section{W. Vetter}

Institute of Food Chemistry (170b), University of

Hohenheim, 70599 Stuttgart, Germany

e-mail: walter.vetter@uni-hohenheim.de

\section{Lewandowski $(\bowtie)$}

Department of Biobased Products and Energy Crops

(340b), University of Hohenheim, Fruwirthstr. 23,

70599 Stuttgart, Germany

e-mail: iris_lewandowski@uni-hohenheim.de 
temperature was observed. The oil chemical composition was similar to that reported for Elaeis guineensis, suggesting that Acrocomia aculeata from Costa Rica may be a suitable alternative for industrial applications currently based on African palm oil. Analysis of husks as a coproduct revealed the possibility of obtaining materials with high lignin and low water and ash contents that could be used as a solid bioenergy source. In conclusion, Acrocomia aculeata oil is a promising alternative for industrial applications currently based on African palm oil and byproducts of its oil production could find additional use as a renewable energy source.

Keywords Coyol palm $\cdot$ Macauba palm $\cdot$ Multipurpose crop · Fruit biometric parameters .

Vegetable oil · Fatty acid composition

\section{Introduction}

Vegetable oil is an important raw material for food production, but also for the manufacture of bio-based products, such as detergents, cosmetics, and biofuels (Montoya et al. 2016). For this reason, both vegetable oil demand and production have increased during the last decade and are expected to continue to rise in future (Colombo et al. 2018). Due to their high yield potential and low production costs, oleaginous palms are considered the most promising species for vegetable oil production (Poetsh et al. 2012; Del Río et al. 2016; Colombo et al. 2018). Among oleaginous palms, Acrocomia aculeata may be a profitable and sustainable alternative for oil production (Colombo et al. 2018). Previous studies suggest the cultivation of this species in rural areas of Central and South America has high industrial potential with socioeconomic and environmental advantages (Lopes et al. 2013; Plath et al. 2016).

Acrocomia aculeata is a perennial, fruit-bearing palm belonging to the Arecaceae family. It extends throughout the Neotropical region, from Mexico to Argentina (Crocomo and Melo 1996; Plath et al. 2016), mainly in open pasture areas, in disturbed forests and in association with crops (BarbosaEvaristo et al. 2018). A. aculeata grows optimally in tropical and subtropical regions with high precipitation and solar irradiation (César et al. 2015). However, it is robust and adapts well to other environments, including subtropical and semiarid conditions (Del Río et al. 2016).

The Acrocomia palm has additional characteristics relevant for its future cultivation as an oil crop, such as tolerance of long drought periods and nutrient-deficient soils. Moreover, it promotes recovery of marginal soils (César et al. 2015) and, to date, there are no reports of relevant diseases affecting wild Acrocomia populations (Plath et al. 2016; Colombo et al. 2018). In addition, it has been shown that cultivation of Acrocomia in agroforestry systems increases the productivity and yield of the cocultivated crops (Moreira et al. 2018).

Acrocomia has not yet been domesticated and biometry, oil yield, and composition have only been studied in wild genotypes in Brazil (Cardoso et al. 2017; Coelho et al. 2019), where large phenotypic variability has been associated with environmental conditions and genetic diversity (Abreu et al. 2012). The breeding of genetically improved plants with optimized height, increased productivity and drought tolerance is one of the major directions in present Acrocomia research (Cardoso et al. 2017; Colombo et al. 2018). In studies from Brazil, it was found that productivity - in terms of oil yield-is determined by fruit size and oil content, which are in turn related to environmental parameters (e.g. soil conditions, water availability), as well as genetic variability (Ciconini et al. 2013; Castro et al. 2017; Coelho et al. 2019). In these studies, the best performance-in terms of productivity, fruit characteristics and oil contentwere found in regions with higher precipitation and mild temperatures, both typical features of the Atlantic Rainforest (Castro et al. 2017).

Despite the economic potential of Acrocomia in Costa Rica, native populations have not been sufficiently characterized (Schex et al. 2018). Neither has the potential effect of climatic/edaphic conditions on biometric parameters and their relation to oil content and fatty acid composition-as observed in other oleaginous plants (Rached et al. 2017; Tous and Romero 2017) - been investigated. However, the commercialization of Acrocomia production in Costa Rica requires the selection and breeding of the most suitable genotypes for the specific location, which must be guided by knowledge of genotype and environment interactions. The aim of this study was to contribute to this knowledge by investigating the 
influence of fruit biometric parameters of the native palm A. aculeata on oil content and composition under different climatic conditions in Costa Rica.

\section{Materials and methods}

\section{Plant material}

Fruits were collected at the end of the harvest season between July and August 2018 from wild A. aculeata palms located at three sites in Costa Rica: El Coyol, Alajuela, Alajuela $\left(\mathrm{N} 10^{\circ} 00^{\prime} 10.0^{\prime \prime}, \mathrm{W} 84^{\circ} 15^{\prime} 14.5^{\prime \prime}\right.$ and $\mathrm{N} 10^{\circ} 00^{\prime} 19.5^{\prime \prime}, \mathrm{W} 84^{\circ} 14^{\prime} 57.4^{\prime \prime}$, altitude 849 and 860 m.a.s.l., average annual temperature of $25^{\circ} \mathrm{C}$, annual precipitation of $1750 \mathrm{~mm}$ ), La Garita, Alajuela, Alajuela $\left(\mathrm{N} 10^{\circ} 00^{\prime} 11.7^{\prime \prime}, \mathrm{W} 84^{\circ} 16^{\prime} 13.7^{\prime \prime}\right.$, altitude 840 m.a.s.l., average annual temperature of $22{ }^{\circ} \mathrm{C}$, annual precipitation of $1940 \mathrm{~mm}$ ) and La Palma, Palmar, Puntarenas (N8 $38^{\prime} 41.6^{\prime \prime}$, W83 ${ }^{\circ} 27^{\prime} 33.7^{\prime \prime}$, altitude 16 m.a.s.l., average annual temperature of $28^{\circ} \mathrm{C}$, annual precipitation of $3500 \mathrm{~mm}$ ) (Fig. 1, Table 1). Climatic data of each site are reported as long-term historic average values and were obtained from monitoring systems at Universidad de Costa Rica and National Meteorology Institute (Instituto Meteorológico Nacional, San José, Costa Rica). One palm from the regions La Palma and La Garita and two palms from El Coyol were randomly chosen for fruit collection. As is common practice for Acrocomia harvesting, completely ripe fresh fruits (20-70 according to availability) were collected from each palm from the ground shortly after falling from the fruit bunch. The fruit ripening stage was defined according

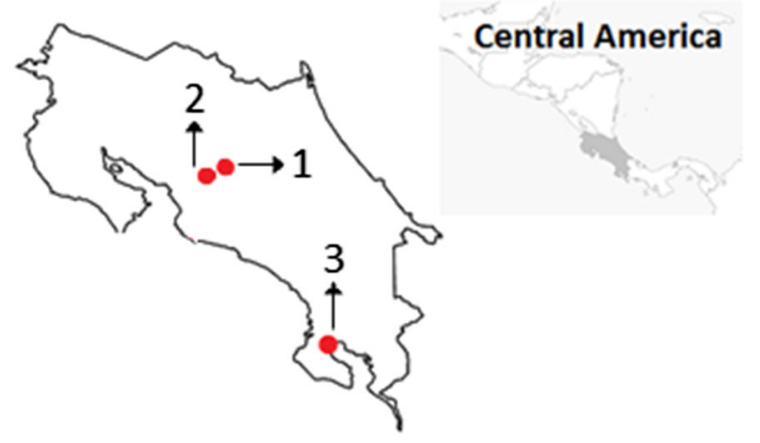

Fig. 1 Location of the three harvesting sites in Costa Rica. 1: El Coyol (Alajuela), 2: La Garita (Alajuela) and 3: La Palma (Puntarenas) to previous reports (Schex et al. 2018). Fully ripe fruits detach naturally from the bunch (Crocomo and Melo 1996; Montoya et al. 2016) and display a brown exocarp and a yellow mesocarp (Schex et al. 2018; Lieb et al. 2019). Soil samples were taken at each location and analyzed for texture and chemical properties (Appendix 1).

\section{Biometric analysis}

A randomized sample $(n=5)$, chosen blind from a bucket, was taken from each location to assess transversal and longitudinal diameter, and fresh and dry weight of the different fruit structures (husk, pulp, shell and kernel; Fig. 2). For moisture determination, fresh fruits were separated into the structures mentioned above. They were dried separately in a forcedair oven at $60{ }^{\circ} \mathrm{C}$ for $72 \mathrm{~h}$ and moisture content was determined gravimetrically.

\section{Sample pretreatment}

For lipid quantification and fatty acid profiling, eight fresh fruits from each location were randomly chosen, manually peeled, and pulp and kernel were immediately frozen in liquid nitrogen to avoid degradation. Samples were freeze-dried for $72 \mathrm{~h}$ under light protection in a laboratory freeze-dryer (Alpha 1-2 LD Christ, Osterode, Germany) at $-50{ }^{\circ} \mathrm{C}$ and transported to Germany in vacuum-sealed polyethylene bags covered with aluminum foil.

Processing for ash and fiber content determination was based on the methodology described by Kiesel et al. (2017). The husk of approximately 50 randomly chosen fruits from each location was separated manually, weighed, dried with a forced-air oven at $60{ }^{\circ} \mathrm{C}$ for $72 \mathrm{~h}$ and transported to Germany in vacuum-sealed polyethylene bags.

Chemical analysis

\section{Quantification of total lipid content}

Samples from each location were individually ground using a commercial coffee grinder and aliquots of $1.5 \mathrm{~g}$ were extracted in triplicate using $20 \mathrm{~mL} n$ hexane (HPLC grade) for $30 \mathrm{~min}$ under continuous agitation at room temperature $\left(20-25{ }^{\circ} \mathrm{C}\right)$. The hexane fraction containing the lipid extract was vacuum- 
Table 1 Climatic data and characteristics of fruit collection sites of Acrocomia aculeata in Costa Rica. Source: Instituto Meteorológico Nacional, San José, Costa Rica

\begin{tabular}{lllll}
\hline Location & $\begin{array}{l}\text { Altitude } \\
\text { (m.a.s.l.) }\end{array}$ & $\begin{array}{l}\text { Annual average } \\
\text { temperature }\left({ }^{\circ} \mathrm{C}\right)\end{array}$ & $\begin{array}{l}\text { Average Precipitation } \\
(\mathrm{mm} / \text { year })\end{array}$ & $\begin{array}{l}\text { Average relative } \\
\text { humidity }(\%)\end{array}$ \\
\hline El Coyol & 860 & 25 & 1750 & 72 \\
La Garita & 849 & & & 72 \\
La Palma & 840 & 22 & 1940 & 89 \\
\hline
\end{tabular}

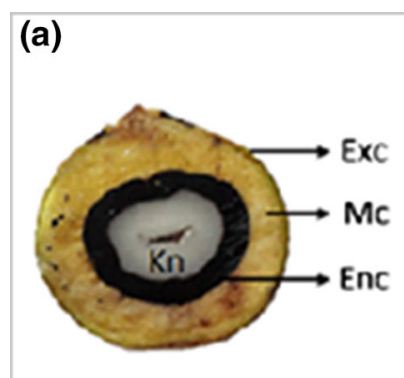

(b)

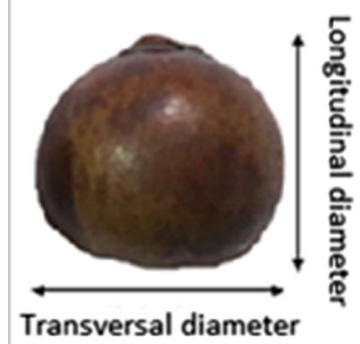

Fig. 2 Biometrical features of Acrocomia aculeata fruit. a Transversal view of a sectioned fruit; Exc exocarp (husk), $M c$ mesocarp (pulp), Enc endocarp (shell) and Kn kernel (seed).

filtered through a $0.2 \mu$ m polyether sulfone membrane filter (Sigma Aldrich, Germany) and recovered in a distillation flask. The solvent was removed by rotary evaporation at $30{ }^{\circ} \mathrm{C}$ and 250 mbar until dryness. Lipid content was determined gravimetrically. Lipid extracts from the same location were pooled and stored protected from light and humidity at $-80{ }^{\circ} \mathrm{C}$.

\section{Preparation of fatty acid methyl esters (FAMEs)}

Transesterification was performed according to Wendlinger et al. (2014). An aliquot of the lipid extract was placed into a reaction tube and the solvent evaporated under a gentle stream of nitrogen. Then, $1 \mathrm{~mL}$ of $1 \%$ b Transversal and longitudinal diameters. c Fruit fresh biomass after the separation of structures

sulfuric acid in methanol (v/v) was added and the tube incubated at $80{ }^{\circ} \mathrm{C}$ for $1 \mathrm{~h}$ with occasional shaking. After cooling down the sample on ice, $0.5 \mathrm{~mL}$ demineralized water, $0.5 \mathrm{~mL}$ saturated $\mathrm{NaCl}$ solution and $2 \mathrm{~mL} n$-hexane were added, mixed by vortex and centrifuged at $1000 \mathrm{rpm}$ for $3 \mathrm{~min}$. Subsequently, $1 \mathrm{~mL}$ of the $n$-hexane supernatant was transferred into a $1.5 \mathrm{~mL}$ vial for instrumental analysis.

FAMEs were identified by gas chromatography with mass spectrometry (GC/MS) using a 5890 series II Plus/5972 system in combination with a 7673 autosampler (Hewlett-Packard/Agilent, Waldbronn, Germany) operated in full-scan mode. An Rtx 2330 capillary column $(60 \mathrm{~m} \times 0.25 \mathrm{~mm}$ coated with 
$0.1 \mu \mathrm{m} \mathrm{10 \%}$ cyanopropylphenyl, $90 \%$ bis-cyanopropyl polysiloxane; Restek, Bellefonte, PA, USA) was used in combination with the following oven program. After $1 \mathrm{~min}$ at $60^{\circ} \mathrm{C}$, the temperature was raised by $6{ }^{\circ} \mathrm{C} / \mathrm{min}$ to $150{ }^{\circ} \mathrm{C}$, then by $4{ }^{\circ} \mathrm{C} / \mathrm{min}$ to $190{ }^{\circ} \mathrm{C}$, and finally by $7{ }^{\circ} \mathrm{C} / \mathrm{min}$ to $250{ }^{\circ} \mathrm{C}$, which was held for 7 min (Wendlinger et al. 2014). Helium (purity 5.0) was used as carrier gas at a flow rate of $1.2 \mathrm{~mL} / \mathrm{min}$. Peak identification was based on retention times and mass spectra in comparison with commercial standards (Sigma Aldrich, Taufkirchen, Germany).

Fatty acid profiles were determined as FAMEs by gas chromatography with flame ionization detection (GC/FID) using a 5890 series II system in combination with a 7673A autosampler (Hewlett-Packard/Agilent, Waldbronn, Germany). Oven program and column were identical to those described above for GC/MS.

\section{Determination of ash and fiber content of husks}

Analyses were conducted following the methodology applied by Kiesel et al. (2017). Dried husks from each location were processed by a SM-200 cutting mill equipped with a 1-mm sieve. For ash determination, the husk samples were incinerated in a muffle kiln at $550{ }^{\circ} \mathrm{C}$ for $4 \mathrm{~h}$ according to VDLUFA book III method 8.1 and ash content was determined gravimetrically. The contents of neutral detergent fiber (NDF), acid detergent fiber (ADF) and acid detergent lignin (ADL) were estimated for husk fractions by near infrared spectroscopy (NIRS), using a ANKOM2000 Fiber Analyzer coupled to a Daisy II Incubator, according to VDLUFA book III method 6.5.1 (NDF), 6.5.2 (ADF), and 6.5.3 (ADL) (Naumann et al. 1976). The ADL value was considered lignin content; ADF minus ADL was considered cellulose content and NDF minus ADF was considered hemicellulose content. The ash and NDF/ADF/ADL analysis was carried out twice for each sample.

\section{Statistical analyses}

Statistical analyses were performed using the software Minitab ${ }^{\circledR}$ 18. Normality of data was checked by Anderson-Darling test (Appendix 2) and homogeneity of variances was assessed by Levene's test (Appendix 3). Analysis of variance (ANOVA) was used to assess significant differences in morphological and chemical characteristics of fruits between locations. The means of significantly different data were compared by Tukey test (HSD). Spearman's Rho test was performed to assess correlations between oil yield and environmental and soil parameters. A significance value $(\alpha)$ of 0.05 was used for all statistical tests.

\section{Results}

Biometric analyses

Biometric data of the fruits obtained from Costa Rican A. aculeata are shown in Table 2. The size and weight of the fruits varied between the different locations. The largest fruits, in terms of transverse and longitudinal diameter, were found at the location "El Coyol", and these were also significantly heavier than those collected in "La Garita" and "La Palma".

There were significant differences in relative proportions of the various structures between fruits from "La Palma" and the other two locations. "La Palma" fruits had the highest proportion of husk $(32.4 \pm 2.1 \%)$ and lowest relative proportion of shell $(17.5 \pm 1.2 \%)$. The pulp mass of fruits from all three was between 44 and $49 \%$ of total fruit weight with significant differences being observed between locations (Table 2). The kernel fractions differed significantly with a share of $9.07 \pm 0.96 \%$ in "La Garita", $7.82 \pm 0.95 \%$ in "El Coyol" and $5.92 \pm 0.48 \%$ in "La Palma".

Quantification of total lipid content

Moisture and lipid contents of the different structures are shown in Table 3. As expected, the moisture content was much higher in the pulp than the kernels, while a higher oil content was observed in the kernels. Kernel moisture did not differ between locations. Pulp moisture content was highest in the "La Palma" samples, followed by "La Garita" and then by " $\mathrm{El}$ Coyol". The analysis of variance suggested that the geographical origin also had an impact on the oil content of ripe A. aculeata fruit pulp. The location with the highest oil content was "La Palma", with a mean value of $39.6 \pm 2.1 \mathrm{~g}$ oil $/ 100 \mathrm{~g}$ in the dried pulp. The lipid content in Costa Rican A. aculeata kernels showed no significant differences between the studied locations. The overall average oil content sampled was around 54\% of the total kernel mass on a 
Table 2 Biometric characteristics of Costa Rican Acrocomia aculeata fruits collected from three different locations (mean values within columns not sharing a common superscript letter are significantly different at $P<0.05$ )

\begin{tabular}{llllllll}
\hline Location & \multirow{2}{*}{ Fresh weight of fruit $(\mathrm{g})$} & \multicolumn{2}{l}{ Structure weight of fresh material $(\mathrm{g})$} & & \multicolumn{2}{c}{ Diameter $(\mathrm{cm})$} \\
\cline { 3 - 6 } & & Husk & Pulp & Shell & Kernel & Transverse & Longitudinal \\
\hline El Coyol & $45.0 \pm 3.0^{\mathrm{a}}$ & $10.6 \pm 1.9^{\mathrm{a}}$ & $21.0 \pm 3.9^{\mathrm{a}}$ & $9.9 \pm 1.3^{\mathrm{a}}$ & $3.5 \pm 0.5^{\mathrm{a}}$ & $4.5 \pm 0.1^{\mathrm{a}}$ & $4.4 \pm 0.1^{\mathrm{a}}$ \\
La Garita & $33.0 \pm 3.7^{\mathrm{c}}$ & $6.9 \pm 0.8^{\mathrm{b}}$ & $16.2 \pm 2.0^{\mathrm{b}}$ & $7.3 \pm 1.2^{\mathrm{b}}$ & $3.0 \pm 0.5^{\mathrm{a}}$ & $4.1 \pm 0.2^{\mathrm{b}}$ & $4.0 \pm 0.1^{\mathrm{c}}$ \\
La Palma & $39.6 \pm 3.0^{\mathrm{b}}$ & $12.9 \pm 2.8^{\mathrm{a}}$ & $17.5 \pm 1.1^{\mathrm{ab}}$ & $6.9 \pm 0.3^{\mathrm{b}}$ & $2.3 \pm 0.2^{\mathrm{b}}$ & $4.2 \pm 0.1^{\mathrm{b}}$ & $4.2 \pm 0.1^{\mathrm{b}}$ \\
\hline
\end{tabular}

Table 3 Moisture and lipid content in main structures of Costa Rican Acrocomia aculeata fruits collected from three different locations (mean values within columns not sharing a common superscript letter are significantly different at $P<0.05$ )

\begin{tabular}{|c|c|c|c|c|}
\hline \multirow[t]{2}{*}{ Location } & \multicolumn{2}{|c|}{ Moisture ( $\mathrm{g} / 100 \mathrm{~g}$ fresh material) } & \multicolumn{2}{|c|}{ Lipid content (g/100 g dry matter) } \\
\hline & Kernel & Pulp & Kernel & Pulp \\
\hline El Coyol & $14.9 \pm 4.7^{\mathrm{a}}$ & $47.2 \pm 5.7^{\mathrm{c}}$ & $48.7 \pm 4.9^{\mathrm{b}}$ & $26.6 \pm 2.2^{\mathrm{c}}$ \\
\hline La Garita & $17.7 \pm 3.1^{\mathrm{a}}$ & $57.5 \pm 3.7^{\mathrm{b}}$ & $58.4 \pm 2.1^{\mathrm{a}}$ & $33.5 \pm 2.0^{\mathrm{b}}$ \\
\hline La Palma & $19.2 \pm 0.7^{\mathrm{a}}$ & $66.4 \pm 3.2^{\mathrm{a}}$ & $53.7 \pm 0.7^{\mathrm{ab}}$ & $39.6 \pm 2.1^{\mathrm{a}}$ \\
\hline
\end{tabular}

dry basis (lowest value: $48.7 \pm 4.9 \%$, highest value: $58.4 \pm 2.1 \%)$.

Fatty acid profiles

Fatty acid profiles for both kernel and pulp are shown in Fig. 3.

The fatty acid profile of the lipid fraction obtained from kernels revealed that, in all locations, lauric acid (12:0) was the most abundant (40.9\%), followed by oleic acid (18:1n-9) and myristic (14:0) acid (20.2\% and $12.0 \%$, respectively). The remaining percentage is represented in descending order by caprylic (8:0), palmitic (16:0), capric (10:0), linoleic $(18: 2 n-6)$ and stearic acid (18:0).

A lower proportion of the saturated lauric acid was found in samples from "La Palma" $(36.0 \pm 1.1 \%)$ than in the other locations $(44.5 \pm 1.6 \%$ and $41.9 \pm 2.2 \%$ ). The "La Palma" location also had a significantly higher content of $18: 1 n-9$, accounting for $26.4 \pm 0.2 \%$ of total fatty acids, while an average of $17.2 \%$ was determined for " $E l$ Coyol" and " $\mathrm{La}$ Garita". Capric and caprylic acids also showed significant differences between locations, the lowest being found in "La Palma". The opposite tendency was observed for stearic, linoleic and palmitic acids, which were higher at this location.
Analysis of the lipid fraction obtained from the pulp identified six fatty acids, predominantly oleic acid (18:1n-9, and possibly its isomer vaccenic acid), followed by the saturated palmitic acid (16:0) and smaller amounts of stearic (18:0), palmitoleic $(16: 1 n$ 7), linoleic (18:2n-6) and $\alpha$-linoleic acid (18:3n-3). In contrast to kernel oils, no fatty acids with a chain length shorter than 16 carbons were detected in pulp oil. The 18:1 isomer concentration was significantly higher in pulp oil from "La Palma" $(76.4 \pm 0.2 \%)$ than in the other two locations $(47.6 \pm 7.0 \%$ and $45.1 \pm 1.8 \%$ ). By contrast, the second most abundant fatty acid (palmitic acid) had a significantly lower proportion in "La Palma" $(14.0 \pm 0.0 \%)$ than in the other two locations $(24.5 \pm 2.4 \%$ and $25.7 \pm 0.4 \%)$.

In general, the fatty acid composition of oils obtained from "La Garita" and "El Coyol" had a very similar composition in both kernel and pulp. Those obtained from "La Palma" differed significantly, with a higher content of unsaturated fatty acids mainly in the form of $18: 1$.

\section{Ash, lignin and fiber content of husk}

Lignin was the most abundant organic compound in husks at two of the three locations, followed by cellulose, with hemicellulose being the least abundant 

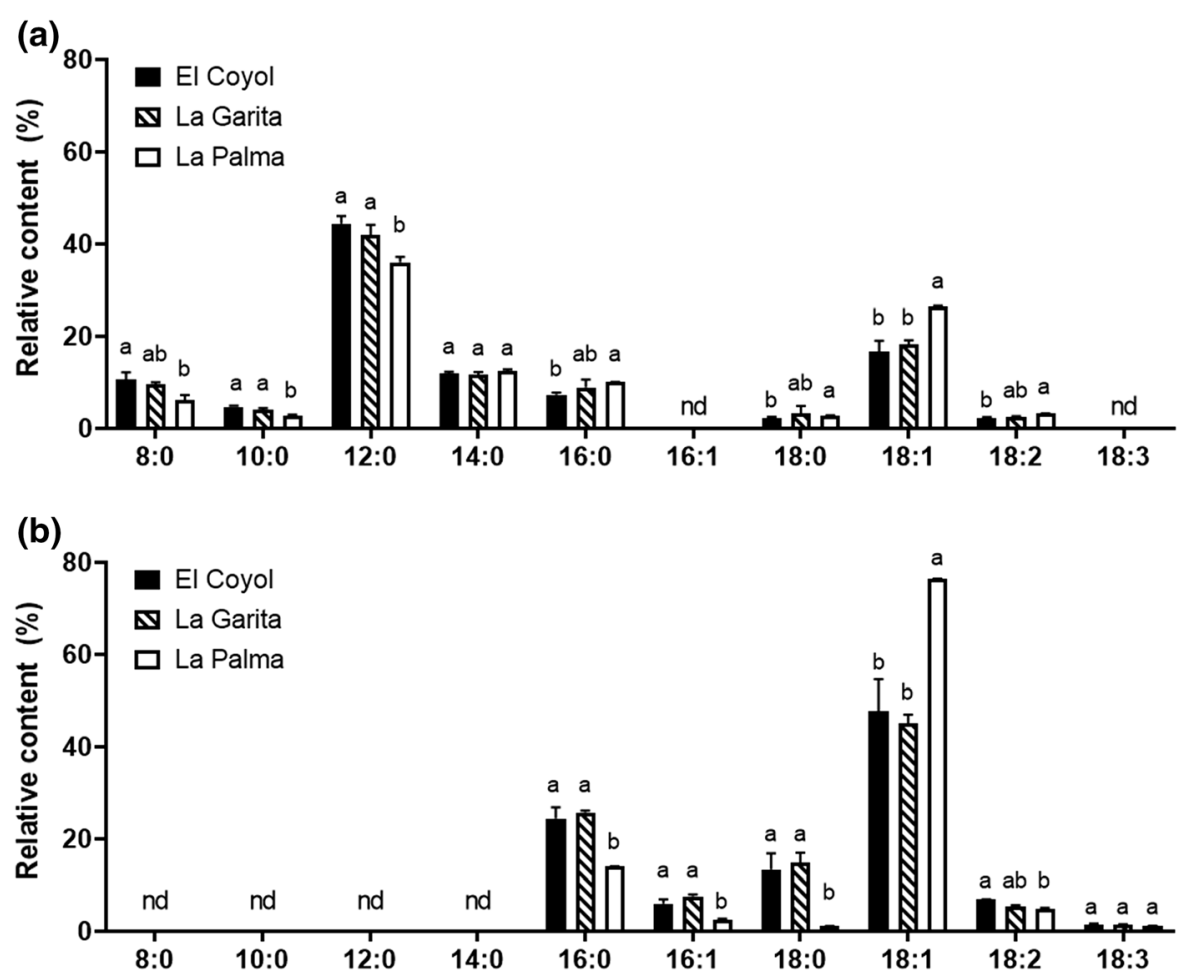

Fig. 3 Fatty acids as methyl esters in kernel (a) and pulp (b) of Costa Rican Acrocomia aculeata from three locations obtained by conventional hexane extraction [values represent arithmetic means \pm standard deviation $(n=3)]$. For each fatty acid, bars not sharing a common superscript letter are significantly different at $P<0.05 ; n d=$ not detected in the sample

Table 4 Moisture, lignin, fiber and ash content in the husk of Costa Rican Acrocomia aculeata fruits collected from three different locations (mean values within columns not sharing a common superscript letter are significantly different at $P<0.05$ )

\begin{tabular}{llllrl}
\hline Location & $\begin{array}{l}\text { Moisture }(\mathrm{g} / 100 \mathrm{~g} \\
\text { fresh material) }\end{array}$ & $\begin{array}{l}\text { Lignin }(\mathrm{g} / 100 \mathrm{~g} \\
\text { dry material) }\end{array}$ & $\begin{array}{l}\text { Cellulose }(\mathrm{g} / 100 \mathrm{~g} \\
\text { dry material) }\end{array}$ & $\begin{array}{l}\text { Hemicellulose }(\mathrm{g} / \\
100 \mathrm{~g} \text { dry material) }\end{array}$ & $\begin{array}{l}\text { Ash }(\mathrm{g} / 100 \mathrm{~g} \\
\text { dry material) }\end{array}$ \\
\hline El Coyol & $42.4 \pm 4.2^{\mathrm{b}}$ & $35.0 \pm 4.8^{\mathrm{a}}$ & $25.9 \pm 1.5^{\mathrm{a}}$ & $11.3 \pm 3.5^{\mathrm{a}}$ & $3.5 \pm 0.5^{\mathrm{a}}$ \\
La Garita & $44.0 \pm 5.7^{\mathrm{b}}$ & $33.6 \pm 3.1^{\mathrm{ab}}$ & $28.0 \pm 0.5^{\mathrm{a}}$ & $5.1 \pm 3.1^{\mathrm{a}}$ & $4.0 \pm 0.1^{\mathrm{a}}$ \\
La Palma & $61.2 \pm 4.6^{\mathrm{a}}$ & $23.2 \pm 0.1^{\mathrm{b}}$ & $27.2 \pm 0.9^{\mathrm{a}}$ & $10.0 \pm 0.4^{\mathrm{a}}$ & $3.8 \pm 0.5^{\mathrm{a}}$ \\
\hline
\end{tabular}

(Table 4). Lignin concentrations (identified as acid detergent lignin) were significantly higher in fruits from "El Coyol" $(35.0 \pm 4.8 \mathrm{~g} / 100 \mathrm{~g} \mathrm{DM})$ than in those from "La Palma" (23.2 $\pm 0.1 \mathrm{~g} / 100 \mathrm{~g}$ DM). Samples from "La Garita" had an intermediate value that did not differ significantly to the other two locations. Cellulose contents varied from $28.0 \pm 0.5 \mathrm{~g} / 100 \mathrm{~g} \mathrm{DM}$ at "La Garita" to $25.9 \pm 1.5 \mathrm{~g} / 100 \mathrm{~g}$ DM at "El Coyol". Ash content was virtually the same for all locations with an average inorganic residue of $3.8 \pm 0.5 \mathrm{~g} / 100 \mathrm{~g} \mathrm{DM}$.

\section{Correlation Analysis}

Significant positive correlations were found between the pulp oil content and precipitation as well as relative humidity. Also, positive correlations were found between pulp oil content and both sand and silt contents of the soils (Table 5). No significant correlations were observed between pulp oil content and annual average temperature. 


\section{Discussion}

This study revealed large variations in biometric parameters and composition between A. aculeata fruits from different accessions in Costa Rica, as has been observed in previous studies performed both in Costa Rica (Schex et al. 2018) and other Latin American regions (Ciconini et al. 2013; Lescano et al. 2015; Castro et al. 2017; Coelho et al. 2019).

The fruits collected in Costa Rica were smaller than to those of Brazilian palms documented in several previous reports (Ciconini et al. 2013; Castro et al. 2017; Vianna et al. 2017). However, even smaller sizes have been reported for $A$. aculeata fruits at a similar maturity stage collected in Costa Rica (Schex et al. 2018) and for some Brazilian accessions (Manfio et al. 2011; Ciconini et al. 2013), indicating strong variability among populations. Large biometric variability is therefore characteristic of wild Acrocomia populations and has been associated with genetic variability and environmental influences - in particular soil chemical properties and soil water availability-on plant functioning (Manfio et al. 2011; Coelho et al. 2019).

Our data suggest that geographical location has a strong influence on the oil content of the pulp of ripe $A$. aculeata fruits from Costa Rica. The highest oil content was observed in "La Palma", with a mean value of $39.6 \pm 2.1 \%$ pulp oil on a dry basis, followed by "La Garita" at $33.5 \pm 2.0 \%$, and "El Coyol" at $26.6 \pm 2.2 \%$ (Table 3). Correlation data revealed that the fruits from the location with the highest annual rainfall and relative humidity (La Palma, Puntarenas) had the highest oil content in pulp (0.895 and 0.709; $p<0.001)$, indicating that precipitation may be an important determinant of oil content. These results are in agreement with other studies from Brazil where $A$. aculeata palms perform better and have higher oil contents in regions with higher precipitation (Castro et al. 2017).

This finding on the strong influence of precipitation is also supported by the even lower oil content previously reported in pulp from fruits collected in "Bagaces" (Guanacaste, Costa Rica), a dry region on the northwest Pacific coast (Schex et al. 2018; Lieb et al. 2019). Additionally, the lowest pulp and kernel oil contents measured in the present study were found in the largest fruits, harvested at the site "El Coyol", suggesting that biometric parameters may also influence oil content. In line with our results, Ciconini et al. (2013) found that smaller A. aculeata fruits growing in Mato Grosso do Sul, Brazil, had higher kernel oil content. Fruit size determination in plants is multifactorial, involving genetic, environmental and other factors such as nutrient availability and pollination efficiency (Guo and Simmons 2011). Other oleaginous crops, such as olive (Olea europaea L.), also reveal an inverse relation between fruit size and oil concentration, which is steered by the source-sink ratio (Trentacoste et al. 2010). However, further observations are required to be able to draw ultimate conclusions for the selection of A. aculeata accessions with the optimal fruit size for high oil contents.

The pulp oil concentration varied significantly between accessions, even between the fruits from the relatively close locations of "La Garita" and " $E l$ Coyol". It can be assumed that closer populations share more genetic similarities, have developed under similar environmental conditions and thus display comparable phenotypic fruit characteristics. However, samples from "La Garita" were obtained from a genotype originating from Brazil whereas those from

Table 5 Spearman Rho correlation test between pulp oil content (g/100 g dry material) and environmental and soil parameters from three different locations in Costa Rica

\begin{tabular}{lcr}
\hline Variable & Correlation coefficient & $P$ value \\
\hline Precipitation $(\mathrm{mm} /$ year) & 0.895 & $\leq 0.001$ \\
Annual temperature $\left({ }^{\circ} \mathrm{C}\right)$ & 0.243 & 0.223 \\
Average relative humidity $(\%)$ & 0.709 & $\leq 0.001$ \\
Sand $(\%)$ & 0.756 & $\leq 0.001$ \\
Slit $(\%)$ & 0.861 & $\leq 0.001$ \\
Clay $(\%)$ & -0.756 & $\leq 0.001$ \\
\hline
\end{tabular}


other origins are assumed to come from more indigenous genotypes. Further analysis of the genetic background of Costa Rican populations is necessary to assess whether they provide suitable material for variety development and how they compare to genotypes of Brazilian origin.

Nevertheless, pulp oil contents of the Costa Rican fruits in this study were higher than those reported for populations in the Brazilian regions of Cerrados, Pantanal (25.1\%) (Ciconini et al. 2013) and Mato Grosso do Sul $(23.6 \pm 1.1 \%)$ (de Oliveira et al. 2017). This may be explained by the lower precipitation in these Brazilian regions and confirms the positive correlation observed in this study between pulp oil content and precipitation level. By contrast, similar levels of pulp oil content to those found in the Costa Rican fruits have been reported for fruits from the Brazilian state of Minas Gerais, although precipitation at that location was relatively low $(1200 \mathrm{~mm})$ (Montoya et al. 2016). This could be related to the large genetic diversity observed in this species (Abreu et al. 2012; Oliveira et al. 2012; Araújo et al. 2017) and the fact that the highest kernel oil content in our Costa Rican study was found for the Acrocomia genotype that originates from Brazil, growing at the location "La Garita".

There were significant differences in kernel oil content between the three locations assessed in this study, with wide variation in values. The mean oil content of 54\% of the total kernel mass (by dry weight; lowest value: $48.7 \pm 4.9 \%$ and highest: $58.4 \pm 2.1 \%$ ) was similar to the 53 and $56 \%$ reported for Costa Rican samples from the "Bagaces" region (Schex et al. 2018; Lieb et al. 2019). It is also comparable to those reported for Brazilian samples (Belén-Camacho et al. 2005; Lescano et al. 2015), with the exception of one publication that cited higher values of $63.5-68.9 \%$ (Ciconini et al. 2013).

These results suggest that the oil content in pulp may be more influenced by environmental or genetic variation than that of kernels. However, although the kernels have a higher oil content than the pulp, the total oil yield from Acrocomia is mainly determined by the oil content of the pulp, as this accounts for a higher mass proportion of the fruit.

The lipids extracted from the pulp and kernel fractions exhibit completely different characteristics, and this has implications for their application in potential final products (Del Río et al. 2016; Souza et al. 2016). The oil extracted from the pulp of $A$. aculeata fruits from Costa Rica was mainly composed of unsaturated fatty acids, while the lipid fraction obtained from the kernels was rich in short-chain saturated fatty acids, predominantly lauric acid. This confirms findings by Coimbra and Jorge (2012) for differences in pulp and kernel oil from Brazilian Acrocomia fruits.

Chemical similarity to oil obtained from the African oil palm (Elaeis guineensis Jacq.) may indicate potential applications for Acrocomia oil. E. guineensis is one of the most important oil crops, accounting for approximately $40 \%$ of global vegetable oil production. Its fatty acid profile and low costs are considered two key factors that make pulp oil from E. guineensis particularly suitable for industrial applications (Choudhary and Grover 2019). By comparison, A. aculeata fruits from Costa Rica had lower proportions of saturated palmitic acid and higher proportions of the monounsaturated oleic acid (Lieb et al. 2017).

Unsaturated fatty acids are considered "healthy" fats because of their beneficial cardiovascular effects (Lunn and Theobald 2006). However, they are more susceptible to oxidation and the generation of undesired compounds, while oils with higher content of saturated fatty acids have a higher oxidative stability and are thus more suitable for a number of industrial applications (Souza et al. 2016). Nonetheless, it has been suggested that despite its unsaturated nature, high concentrations of oleic acid may increase oil oxidative stability and thermal operability at low temperatures and these could be useful characteristics for the food industry and biodiesel production (Nunes et al. 2015; Del Río et al. 2016; Lieb et al. 2017).

The fatty acid composition of pulps from " $\mathrm{La}$ Garita" and "El Coyol" (Alajuela) were the closest to those reported for E. guineensis. For these two neighboring locations, pulp oleic acid content averaged $46.4 \%$ and palmitic acid $25.1 \%$. The composition of the oil extracted from fruit pulps in "La Palma" exhibited completely different characteristics, with higher content of oleic acid (76.4\%) and lower content of palmitic acid (14\%). In general, the fatty acid profiles of the samples taken from Costa Rican $A$. aculeata were similar to those reported for Brazilian accessions, where oleic acid was also the main component (between 55 and 60\%), followed by palmitic acid (between 19 and 23\%) and linoleic acid 
(between 4 and 10\%) (Coimbra and Jorge 2012; Nunes et al. 2015; Del Río et al. 2016; Prates-Valério et al. 2019). For E. guineensis accessions, oleic acid contributed $36 \%$ and palmitic acid 39\% to the total pulp fatty acids (Prates-Valério et al. 2019).

The lipid fraction obtained from E. guineensis kernels is considered a valuable product with applications in the cosmetic, pharmaceutical (Kalustian 1985) and food (Ali and Dimick 1994; Keng et al. 2009) industries. Palm kernel oil and other lauric acidcontaining oils are extensively used in a wide range of cosmetic and pharmaceutical formulations as direct additives or as a source of modified chemical compounds (Kalustian 1985). The fatty acid composition of kernel oil obtained from A. aculeata fruits from Costa Rica showed a similar composition to that of E. guineensis (Kalustian 1985; Keng et al. 2009; Lieb et al. 2017), suggesting that this new source could be used for similar purposes (Belén-Camacho et al. 2005; Coimbra and Jorge 2012; César et al. 2015; Del Río et al. 2016).

E. guineensis kernel oil is rich in lauric acid (between 48 and 55\%) and oleic acid (up to 15\%) (Kalustian 1985; Keng et al. 2009; Lieb et al. 2017). As observed for pulp oil, kernel oil from fruits collected in "El Coyol" and "La Garita" was closer in composition to that of E. guineensis, with $43.4 \%$ lauric acid and $17.2 \%$ oleic acid. However, the fatty acid profile of kernels collected in "La Palma" was considerably lower in lauric acid (36\%) and higher in oleic acid (26.4\%). Kernel oil from "Bagaces" (Guanacaste, Costa Rica) has characteristics similar to those from "El Coyol" and "La Garita", which means that lauric acid was also the predominant fatty acid (41.6-42.9\%), followed by oleic acid (around 20\%) (Lieb et al. 2019). In contrast, the kernel oil extracted from fruits in Minas Gerais (Brazil) displayed a similar chemical composition to the ones from "La Palma", with lower lauric acid (32\%) and higher oleic acid concentrations (28\%) (Coimbra and Jorge 2012; Del Río et al. 2016).

As summarized by Efendy Goon et al. (2019), fatty acid composition of kernel and pulp oils obtained from E. guineensis can be significantly modified by fractioning, bleaching and other industrial operations. The refining of Acrocomia oil may provide oil fractions with different fatty acid compositions for particular industrial applications (Nunes et al. 2015), a field that has not yet been explored for Costa Rican fruits. The development of Acrocomia's potential as a source of enriched lipid fractions may promote an increased valorization of this resource.

Industrial extraction of oil from A. aculeata fruits will result in the production of byproducts mainly from the husk fraction (Colombo et al. 2018; PratesValério et al. 2019). To extend the efficiency of the energy generation process and increase profits, it is advisable to exploit potential byproducts that can provide an added value, for example through use in the production of combustion-derived energy, carbon and activated charcoal (Evaristo et al. 2016).

For combustion, materials with low ash and moisture contents and high lignin content are preferred, since these factors influence the calorific value and thus the energy yield (Kiesel et al. 2017). From a compositional perspective, the husks of the fruits collected from "El Coyol" (with the highest lignin and lowest ash content) were the most suitable for energy generation. However, these fruits did not have the highest husk proportion of the accessions. The largest husk and smallest shell fractions were obtained in the "La Palma" location but these had lower lignin contents than at the other two locations and, consequently, a lower heating value.

After oil extraction, the cakes obtained from both pulp and kernel are mainly composed of fiber and protein (Evaristo et al. 2016) and could potentially be used as animal feed (Traese et al. 2015; Del Río et al. 2016). The chemical composition, in particular with regard to any anti-nutritional compounds and thus the economic potential of this material, needs to be further assessed. However, as these did not form part of this study, they are not addressed here.

Acrocomia is a crop unfamiliar to farmers in Costa Rica. For this reason, its successful adoption requires farmers to be informed of its potential and provided with productive genotypes and effective production technology. The harvest practices applied in this study are those commonly used in the commercial utilization of Acrocomia. However, much of the reported variation in composition of Acrocomia fruits has been attributed to a lack of reproducibility of the harvesting method. Traditional harvesting of Acrocomia fruits involves collecting self-detached fruits lying on the ground. As it is known that the ripening stage has an effect on fruit composition (Montoya et al. 2016; Kiesel et al. 2017), future research should focus on the standardization of harvesting methods. Commercial 
cultivation of Acrocomia may require the development of standardized harvesting protocols, similar to those available for E. guineensis (Nunes et al. 2015).

However, it is to be expected that Acrocomia will be produced in systems different from the plantation management practiced for E. guineensis. Acrocomia adapts more easily to environments with lower competition for light and nutrients than to dense forests (Coelho et al. 2019). Therefore, it is probably more suitable for agroforestry systems than for plantation management. Moreover, in Brazil, Acrocomia has a broader geographical distribution than $E$. guineensis, including dry areas (Cardoso et al. 2017). Thus, Acrocomia could also be grown for oil production in regions or under conditions not suitable for $E$. guineensis. As Acrocomia-unlike E. guineensisoccurs naturally mostly in areas outside of tropical rainforests (Plath et al. 2016), the production of vegetable oil from Acrocomia would not compete with rainforest regions and could reduce the pressure on its deforestation. Instead, Cardoso et al. (2017) recommend the production of Acrocomia in integrated systems. In this way, the benefits of agroforestry systems can be taken advantage of. These include, for example, the improved environmental performance and yields of concomitant crops, as have been reported for intercropping of Acrocomia with coffee (Moreira et al. 2018). At the same time, Acrocomia production allows for the diversification of goods for local producers, as it delivers a high-value agricultural product-i.e. vegetable oil-and multiple by-products, such as press cake and shells suitable for food, feed or energetic uses. However, this is only true if a market for these novel goods exists. For this reason, before farmers are motivated to plant Acrocomia palms, consumer studies need to be performed on the demand for and acceptance of such products. With the observed trend towards high levels of acceptance for (more) sustainably produced goods (see e.g., Koh and Lee 2012), Acrocomia products may have a good chance of adoption by the consumer if appropriate information is provided together with the product.

\section{Conclusions}

Costa Rican Acrocomia aculeata pulp oil is rich in unsaturated fatty acids, especially oleic acid, and kernel oil is rich in short-chain saturated fatty acids, mainly lauric acid. A. aculeata oils have similar compositions to those of the African oil palm $E$. guineensis and may be a more sustainable alternative for applications in the cosmetic, pharmaceutical, chemical and food industries, as well as for the production of biodiesel.

As smaller-sized fruits were found to have higher oil contents, the selection of genotypes with small fruits may be a suitable approach for the breeding of commercial varieties in Costa Rica. However, as the overall fruit yield per palm tree was not assessed in this study, further investigations along these lines are necessary before selection criteria for the most promising genotypes can ultimately be recommended.

For the selection of high oil yielding genotypes for Costa Rican locations, Acrocomia from Brazil should be tested along with native genotypes. Also, selection should rather focus on genotypes with high pulp oil than high kernel oil content because the pulp accounts for a higher mass proportion of the fruit.

Further investigations into genetic diversity, harvesting methodologies and the effect of oil processing on its chemical composition are required to implement agricultural production and industrial applications of vegetable oils from $A$. aculeata.

Its properties make Acrocomia most suitable for integration into agricultural production systems that benefit from an increased yield of concomitant crops and an improved environmental performance. As shown by this study, the farmer can benefit from producing vegetable oils for high-value products, including food, cosmetics and pharmaceuticals, together with by-products that are usable for food, feed, chemicals and energy production.

Acknowledgements Open Access funding provided by Projekt DEAL. Jose David Alfaro-Solís acknowledges a scholarship provided by the Clean Energy Program (PELTEC) and the Student Mobility Program from the Costa Rica Institute of Technology (Instituto Tecnológico de Costa Rica). Alexander Montoya-Arroyo acknowledges a scholarship provided by the Food Security Center (FSC) of the University of Hohenheim, supported by the German Academic Exchange Service (DAAD) with funds from the German Federal Ministry of Economic Cooperation and Development (BMZ). The research stay of Iris Lewandowski in Costa Rica was supported by the DFG (Deutsche Forschungsgemeinschaft) under the program "Initiation of International Collaboration". We thank the company Green Integrated Energies, Bagaces, Costa Rica, especially Anna Neubauer, for support with the logistics of the Acrocomia fruit collection. We also thank Katja Lehnert for her 
support in the laboratory and with data analysis. The manuscript was revised by Nicole Gaudet.

Open Access This article is licensed under a Creative Commons Attribution 4.0 International License, which permits use, sharing, adaptation, distribution and reproduction in any medium or format, as long as you give appropriate credit to the original author(s) and the source, provide a link to the Creative Commons licence, and indicate if changes were made. The images or other third party material in this article are included in the article's Creative Commons licence, unless indicated otherwise in a credit line to the material. If material is not included in the article's Creative Commons licence and your intended use is not permitted by statutory regulation or exceeds the permitted use, you will need to obtain permission directly from the copyright holder. To view a copy of this licence, visit http://creativecommons.org/licenses/by/4.0/.

\section{Appendix 1}

See Table 6.

Table 6 Physical and chemical characteristics of the soil samples collected at each location

\begin{tabular}{llll}
\hline Variable analysed & El Coyol & La Garita & La Palma \\
\hline Sand (\%) & 30 & 42 & 35 \\
Silt $(\%)$ & 8 & 18 & 18 \\
Clay (\%) & 62 & 40 & 47 \\
$\mathrm{pH}$ & 6.5 & 6.6 & 6.4 \\
Acidity (cmol/L) & 0.11 & 0.11 & 0.17 \\
$\mathrm{Ca}(\mathrm{cmol} / \mathrm{L})$ & 13.51 & 12.53 & 23.29 \\
$\mathrm{Mg}(\mathrm{cmol} / \mathrm{L})$ & 4.07 & 4.29 & 9.39 \\
$\mathrm{~K}(\mathrm{cmol} / \mathrm{L})$ & 1.12 & 1.00 & 0.27 \\
$\mathrm{CEC}(\mathrm{cmol} / \mathrm{L})$ & 18.81 & 17.93 & 33.12 \\
$\mathrm{SA}(\%)$ & 0.6 & 0.6 & 0.5 \\
$\mathrm{P}(\mathrm{mg} / \mathrm{L})$ & 2 & 5 & 4 \\
$\mathrm{Zn}(\mathrm{mg} / \mathrm{L})$ & 6.5 & 2.4 & 1.8 \\
$\mathrm{Cu}(\mathrm{mg} / \mathrm{L})$ & 19 & 13 & 9 \\
$\mathrm{Fe}(\mathrm{mg} / \mathrm{L})$ & 72 & 63 & 51 \\
$\mathrm{Mn}(\mathrm{mg} / \mathrm{L})$ & 18 & 3 & 14 \\
$\mathrm{EC}(\mathrm{mS} / \mathrm{cm})$ & 0.3 & 0.2 & 0.1 \\
\hline $\mathrm{CEC}$
\end{tabular}

$C E C$ cation exchange capacity $=$ acidity $+\mathrm{Ca}+\mathrm{Mg}+\mathrm{K}$

$S A$ acidity saturation percentage $=$ acidity $/ \mathrm{CEC}^{*} 100$

$E C$ electric conductivity

\section{Appendix 2}

See Table 7.

Table 7 Verification of data normality by the test of Anderson-Darling with a significance level of 0.05

\begin{tabular}{lllc}
\hline Variable & P value & N & Mean \\
\hline Longitudinal diameter $(\mathrm{cm})$ & 0.841 & 19 & 4.262 \\
Transversal diameter $(\mathrm{cm})$ & 0.416 & 19 & 4.304 \\
Fresh weight of the fruit $(\mathrm{g})$ & 0.569 & 19 & 40.42 \\
Dry weight of the fruit $(\mathrm{g})$ & 0.038 & 15 & 21.8 \\
Fresh weight of the husk $(\mathrm{g})$ & 0.666 & 19 & 10.13 \\
Dry weight of the husk $(\mathrm{g})$ & 0.808 & 19 & 5.126 \\
Fresh weight of the pulp $(\mathrm{g})$ & 0.034 & 19 & 18.79 \\
Dry weight of the pulp $(\mathrm{g})$ & 0.135 & 17 & 8.323 \\
Fresh weight of the shell $(\mathrm{g})$ & 0.504 & 19 & 8.425 \\
Dry weight of the shell $(\mathrm{g})$ & 0.082 & 18 & 6.828 \\
Fresh weight of the kernel $(\mathrm{g})$ & 0.616 & 19 & 3.072 \\
Dry weight of the kernel $(\mathrm{g})$ & 0.436 & 16 & 2.537 \\
\hline
\end{tabular}

\section{Appendix 3}

See Table 8 . 
Table 8 Verification of homogeneity between variances by the test of Levene with a significance level of 0.05

\begin{tabular}{lc}
\hline Variable & P value \\
\hline Longitudinal diameter vs. Location & 0.389 \\
Transversal diameter vs. Location & 0.114 \\
Fresh weight of the fruit vs. Location & 0.928 \\
Fresh weight of the husk vs. Location & 0.287 \\
Fresh weight of the pulp vs. Location & 0.247 \\
Fresh weight of the shell vs. Location & 0.297 \\
Fresh weight of the kernel vs. Location & 0.118 \\
Water content of the husk (\%) vs. Location & 0.914 \\
Oil content in the kernel (\%) vs. Location & 0.645 \\
Oil content in the pulp (\%) vs. Location & 0.702 \\
Capric acid in kernel (\%) vs. Location & 0.484 \\
Lauric acid in kernel (\%) vs. Location & 0.669 \\
Oleic acid in kernel (\%) vs. Location & 0.534 \\
Caprylic acid in kernel (\%) vs. Location & 0.305 \\
Myristic acid in kernel (\%) vs. Location & 0.250 \\
Oleic acid in pulp (\%) vs. Location & 0.234 \\
Palmitic acid in pulp (\%) vs. Location & 0.367 \\
Stearic acid in pulp (\%) vs. Location & 0.169 \\
Linoleic acid in pulp (\%) vs. Location & 0.435 \\
\hline
\end{tabular}

\section{References}

Abreu AG, Priolli RHG, Azevedo-Filho JA et al (2012) The genetic structure and mating system of Acrocomia aculeata (Arecaceae). Genet Mol Biol 35:116-121

Ali ARMd, Dimick PS (1994) Melting and solidification characteristics of confectionery fats: Anhydrous milk fat, cocoa butter and palm kernel stearin blends. J Am Oil Chem Soc 71:803-806. https://doi.org/10.1007/BF02540452

Araújo MRG, de Melo Júnior AF, Menezes EV et al (2017) Fine-scale spatial genetic structure and gene flow in Acrocomia aculeata (Arecaceae): Analysis in an overlapping generation. Biochem Syst Ecol 71:147-154. https:// doi.org/10.1016/j.bse.2017.02.005

Barbosa-Evaristo A, Fernández-Coppel IA, Corrêa-Guimarães A et al (2018) Simulation of macauba palm cultivation: an energy-balance and greenhouse gas emissions analysis. Carbon Manag 9:243-254. https://doi.org/10.1080/ 17583004.2018.1463783

Belén-Camacho DR, López I, García D et al (2005) Evaluación fisico-química de la semilla y del aceite de corozo (Acrocomia aculeata Jacq.). Grasas Aceites 56:311-316

Cardoso A, Laviola BG, Santos GS et al (2017) Opportunities and challenges for sustainable production of A. aculeata through agroforestry systems. Ind Crops Prod 107:573-580. https://doi.org/10.1016/j.indcrop.2017.04. 023

Castro CAdeO, Resende RT, Kuki KN et al (2017) High-performance prediction of macauba fruit biomass for agricultural and industrial purposes using Artificial Neural
Networks. Ind Crops Prod 108:806-813. https://doi.org/10. 1016/j.indcrop.2017.07.031

César ADS, Almeida FDA, De Souza RP et al (2015) The prospects of using Acrocomia aculeata (macaúba) a nonedible biodiesel feedstock in Brazil. Renew Sustain Energy Rev 49:1213-1220. https://doi.org/10.1016/j.rser.2015.04. 125

Choudhary M, Grover K (2019) Palm (Elaeis guineensis Jacq.) Oil. In: Ramadan MF (ed) Fruit oils: Chemistry and functionality. Springer, Cham, pp 789-802

Ciconini G, Favaro SP, Roscoe R et al (2013) Biometry and oil contents of Acrocomia aculeata fruits from the Cerrados and Pantanal biomes in Mato Grosso do Sul, Brazil. Ind Crops Prod 45:208-214. https://doi.org/10.1016/j.indcrop. 2012.12.008

Coelho RM, da Costa CF, de Azevedo Filho JA et al (2019) Non-biotic factors determining plasticity of the prospective oil-rich macauba palm (Acrocomia aculeata). Agrofor Syst 93:771-782. https://doi.org/10.1007/s10457-017-0173-7

Coimbra MC, Jorge N (2012) Fatty acids and bioactive compounds of the pulps and kernels of Brazilian palm species, guariroba (Syagrus oleraces), jerivá (Syagrus romanzoffiana) and macaúba (Acrocomia aculeata). J Sci Food Agric 92:679-684. https://doi.org/10.1002/jsfa.4630

Colombo CA, Berton LHC, Diaz BG, Ferrari RA (2018) Macaúba: a promising tropical palm for the production of vegetable oil. Oil Seeds Fats Crops Lipids 25:9. https://doi. org/10.1051/oc1/2017038

Crocomo OJ, Melo M (1996) Acrocomia species (Macauba Palm). In: Bajaj YPS (ed) Trees IV. Springer, Berlin, pp 3-17 
Daniela D, Lopes C, Steidle Neto AJ, Mendes AA, Pereira DTV (2013) Economic feasibility of biodiesel production from Macauba in Brazil. Energy Econ 40:819-824. https://doi. org/10.1016/j.eneco.2013.10.003

de Oliveira IP, Correa WA, Neves VP et al (2017) Optical analysis of the oils obtained from Acrocomia aculeata (Jacq.) Lodd: Mapping absorption-emission profiles in an induced oxidation process. Photonics 4:1-12. https://doi. org/10.3390/photonics4010003

Del Río JC, Evaristo AB, Marques G et al (2016) Chemical composition and thermal behavior of the pulp and kernel oils from macauba palm (Acrocomia aculeata) fruit. Ind Crops Prod 84:294-304. https://doi.org/10.1016/j.indcrop. 2016.02.018

Efendy Goon D, Sheikh Abdul Kadir SH, Latip NA et al (2019) Palm oil in lipid-based formulations and drug delivery systems. Biomolecules 9:64. https://doi.org/10.3390/ biom 9020064

Evaristo AB, Grossi JAS, Carneiro AdeCO et al (2016) Actual and putative potentials of macauba palm as feedstock for solid biofuel production from residues. Biomass Bioenergy 85:18-24. https://doi.org/10.1016/j.biombioe.2015.11.024

Guo M, Simmons CR (2011) Cell number counts-The fw2.2 and $C N R$ genes and implications for controlling plant fruit and organ size. Plant Sci 181:1-7. https://doi.org/10.1016/ j.plantsci.2011.03.010

Kalustian P (1985) Pharmaceutical and cosmetic uses of palm and lauric products. J Am Oil Chem Soc 62:431-433. https://doi.org/10.1007/BF02541417

Keng PS, Basri M, Zakaria MRS et al (2009) Newly synthesized palm esters for cosmetics industry. Ind Crops Prod 29:37-44. https://doi.org/10.1016/j.indcrop.2008.04.002

Kiesel A, Nunn C, Iqbal Y et al (2017) Site-specific management of miscanthus genotypes for combustion and anaerobic digestion: A comparison of energy yields. Front Plant Sci 8:1-15. https://doi.org/10.3389/fpls.2017.00347

Koh LP, Lee TM (2012) Sensible consumerism for environmental sustainability. Biol Conserv 151:3-6. https://doi. org/10.1016/j.biocon.2011.10.029

Lescano CH, Oliveira IP, Silva LR et al (2015) Nutrients content, characterization and oil extraction from Acrocomia aculeata (Jacq.) Lodd. fruits. Afr J Food Sci 9:113-119. https://doi.org/10.5897/AJFS2014.1212

Lieb VM, Kerfers MR, Kronmüller A et al (2017) Characterization of mesocarp and kernel lipids from Elaeis guineensis Jacq., Elaeis oleifera [Kunth] Cortés, and their interspecific hybrids. J Agric Food Chem 65:3617-3626. https://doi.org/10.1021/acs.jafc.7b00604

Lieb VM, Schex R, Esquivel P et al (2019) Fatty acids and triacylglycerols in the mesocarp and kernel oils of maturing Costa Rican Acrocomia aculeata fruits. NFS J 14-15:6-13. https://doi.org/10.1016/j.nfs.2019.02.002

Lunn J, Theobald HE (2006) The health effects of dietary unsaturated fatty acids. Nutr Bull 31:178-224. https://doi. org/10.1111/j.1467-3010.2006.00571.x

Manfio CE, Motoike SY, dos Santos CEM et al (2011) Repetibilidade em características biométricas do fruto de macaúba. Ciênc Rural 41:70-76. https://doi.org/10.1590/ s0103-84782011000100012

Montoya SG, Motoike SY, Kuki KN, Couto AD (2016) Fruit development, growth, and stored reserves in macauba palm
(Acrocomia aculeata), an alternative bioenergy crop. Planta 244:927-938. https://doi.org/10.1007/s00425-0162558-7

Moreira SLS, Pires VC, Marcatti GE et al (2018) Intercropping of coffee with the palm tree, macauba, can mitigate climate change effects. Agric For Meteorol 256-257:379-390. https://doi.org/10.1016/j.agrformet.2018.03.026

Naumann C, Bassler R, Seibold R, Barth C (1976) Die chemische Untersuchung von Futtermitteln. Methodenbuch. Band III. VDLUFA - Verlag, Darmstadt

Nunes AA, Favaro SP, Galvani F, Miranda CHB (2015) Good practices of harvest and processing provide high quality macauba pulp oil. Eur J Lipid Sci Technol 117:2036-2043. https://doi.org/10.1002/ejlt.201400577

Oliveira D, Melo Júnior A, Brandão M et al (2012) Genetic diversity in populations of Acrocomia aculeata (Arecaceae) in the northern region of Minas Gerais, Brazil. Genet Mol Res 11:531-538

Plath M, Moser C, Bailis R et al (2016) A novel bioenergy feedstock in Latin America? Cultivation potential of Acrocomia aculeata under current and future climate conditions. Biomass Bioenergy 91:186-195. https://doi. org/10.1016/j.biombioe.2016.04.009

Poetsh J, Haupenthal D, Lewandowski I et al (2012) Acrocomia aculeata: a sustainable oil crop. Rural 21:41-44. https:// doi.org/10.1016/S0168-583X(03)00650-5

Prates-Valério P, Celayeta JMF, Cren EC (2019) Quality parameters of mechanically extracted edible macauba oils (Acrocomia aculeata) for potential food and alternative industrial feedstock application. Eur J Lipid Sci Technol 121:1-8. https://doi.org/10.1002/ejlt.201800329

Rached MB, Galaverna G, Cirlini M et al (2017) Pedologic factors affecting virgin olive oil quality of "Chemlali" olive trees (Olea europaea L.). J Oleo Sci 66:907-915. https://doi.org/10.5650/jos.ess17066

Schex R, Lieb VM, Jiménez VM et al (2018) HPLC-DADAPCI/ESI-MSn analysis of carotenoids and $\alpha$-tocopherol in Costa Rican Acrocomia aculeata fruits of varying maturity stages. Food Res Int 105:645-653. https://doi.org/ 10.1016/j.foodres.2017.11.041

Souza GK, Scheufele FB, Pasa TLB et al (2016) Synthesis of ethyl esters from crude macauba oil (Acrocomia aculeata) for biodiesel production. Fuel 165:360-366. https://doi. org/10.1016/j.fuel.2015.10.068

Tous J, Romero A (2017) The influence of growing region and cultivar on olives and olive oil characteristics and on their functional constituents. In: Kiritsakis A, Shahidi F (eds) Olives and olive oil as functional foods: bioactivity, chemistry and processing. Wiley, pp 45-80

Traese GK, Castro LHA, Silva PVB et al (2015) Assessment of the cytotoxic, genotoxic, and mutagenic potential of Acrocomia aculeata in rats. Genet Mol Res 14:585-596. https://doi.org/10.4238/2015.January.26.13

Trentacoste ER, Puertas CM, Sadras VO (2010) Effect of fruit load on oil yield components and dynamics of fruit growth and oil accumulation in olive (Olea europaea L.). Eur J Agron 32:249-254. https://doi.org/10.1016/j.eja.2010.01. 002

Vianna SA, Berton LHC, Pott A et al (2017) Biometric characterization of fruits and morphoanatomy of the mesocarp 
of Acrocomia species (Arecaceae). Int J Biol 9:78-92. https://doi.org/10.5539/ijb.v9n3p78

Wendlinger C, Hammann S, Vetter W (2014) Various concentrations of erucic acid in mustard oil and mustard. Food Chem 153:393-397. https://doi.org/10.1016/j.foodchem. 2013.12.073
Publisher's Note Springer Nature remains neutral with regard to jurisdictional claims in published maps and institutional affiliations. 